\title{
TREATMENT OF WASTEWATER FROM CAR WASHES USING A BIOFILTER
}

\author{
Sussie Söderlundh \\ Britt-Marie Svensson \\ Lennart Mårtensson \\ Kristianstad University, Sweden
}

\begin{abstract}
This project investigates the treatment of wastewater from two car washes using a biofilter of peat and carbon-containing ash. An evaluation of the efficiency and waste handling of the filter material was done from an environmental perspective. The biofilters were used during 2 and 4 years respectively. The treatment included an oil separator and a peat/ash biofilter. The main function of the oil separator was to reduce the amount of oil in the wastewater. The peat/ash biofilter was used as a second step of the system to treat mainly heavy metals. A comparison with the guiding values for wastewater from car washes in the municipality of Kristianstad showed that this type of filter works well. Wastewater from car washes may contain many different unhealthy and environmentally dangerous substances such as surfactants and aromatic compounds. More tests are needed to investigate if the treatment method reduces such parameters from the wastewater as well. After usage the filter is considered solid waste and is to be classified and handled according to that. Classification of the filter as waste requires knowledge about the content of environmentally harmful substances in products used in the car washes. As the content of non-analyzed substances in the filters was unknown, combustion was regarded to be an environmentally good way of disposing the filter material as both energy and ashes are recycled.
\end{abstract}

\section{KEYWORDS}

Car wash; Wastewater; Treating method; Guiding values; Bio filter; peat; Carbon-containing ash.

\section{INTRODUCTION}

The members of the European Union have agreed upon solving the environmental problems of today now and leaving a world to the next generation where environmental problems have a solution [1]. In Sweden, 16 environmental objectives have been adopted in the aspiration towards creating a sustainable society. A lot of environmentally harmful substances are produced today, either as merchandises or as by-products. Several of these substances end up in the soil and in streams in nature where they can have a negative impact on the health of humans and other organisms, both in a short and in a long period of time [2]. 
To be able to reach several of the environmental objectives it is an important measure to reduce the emissions of environmentally harmful substances. For that reason requirements and recommendations concerning such emissions have been made more stringent [3].

\subsection{Wastewater from car washes - an environmental problem}

Wastewater that risk polluting lakes and streams is produced when cars are washed. If the washing is done on the street it is very likely that polluted wastewater will go down in the storm water system and end up in a recipient untreated. Car washes in Sweden must have oil separators installed. If washing takes place in a car wash, the water eventually will end up either in a sewage treatment plant, where pollutants might harm microorganisms important in the treatment processes, or go straight into a recipient [4]. The pollutions consist of heavy metals, organic substances such as oil products (non-polar aliphatic hydrocarbons) and inorganic compounds. An estimated 5000 tonnes of abstergent chemicals are used each year when cars are washed in car washes and on the streets in Sweden. The chemicals consist for example of aromatic solvents and surfactants (surface active agents) which are harmful to organisms living in water. Surfactants are used in all car shampoos, may be hard to degrade and are easily bioaccumulating as they are lipophilic. Car shampoos that are eco labelled consist of more easily biodegradable substances and have a less negative impact on the environment [5].

Demands concerning treatment of wastewater from car washes in the municipality of Kristianstad were tightened up in 2005. At the end of 2010 all car washes in the municipality must have a system in which wastewater is treated to meet the guiding values for wastewater from car washes set up by the municipality [6].

\subsection{Peat and carbon-containing ash as a filter material}

A filter made of approximately $75 \%$ peat and $25 \%$ carbon-containing ash has been considered to be a cost effective filter material and has been shown to successfully reduce concentrations of metals in leachate [7-9]. The same kind of filter has been used to treat wastewater from two car washes in the municipality of Kristianstad during two and four years respectively.

The aim of this study has been to investigate if the filter has worked adequately to treat this kind of wastewater in comparison to the guiding values for wastewater from car washes in the municipality of Kristianstad. The aim has also been to investigate what kind of waste the used filter material should be classified as and how it should be handled as waste in the best way from an environmental perspective.

Peat is a natural material which is produced when organic matter is incompletely decomposed under anaerobic conditions. It mainly consists of carbohydrates such as cellulose and hemicellulose. It also consists of humic and fulvic acids, large molecules with high water absorbent capacity. These molecules also have a great ion exchanging capacity which makes peat a good filter for water containing metals. Peat also contains minerals and metals naturally [10]. Besides the exchanging of ions, particles are also caught through physical filtering in the peat. Organic compounds that are caught in the filter may be decomposed by biological processes [11].

Carbon-containing ash was mixed with the peat as a cheap substitute for activated carbon for removal of organic, hydrophobic compounds [8].

An effective filter does not just catch particles in water flowing through it, it is also important that it does not leach substances that are in the filter from the beginning or that have been 
caught during it's time of use. Leaching test on both used and unused filter material of peat and carbon-containing ash have shown that only very low proportions of different components were leached out from both the unused and the used filter[8].

\subsection{Waste classification}

According to Swedish law, operators have the responsibility to gain knowledge about what impact the businesses have on the environment and on the health of people and prevent negative impact from happening by planning and controlling activities continuously [12]. Operators of car washes where 5000 cars or more are cleaned per year are obliged to document routines that prevent environmental and health problems and to keep a list of all chemical products used in the business that may be of risk to the environment and to people's health [13].

A used filter is waste and needs to be correctly classified as such and handled in an acceptable way from a health and environmental perspective by the owner of the filter [12]. A filter made of peat and ash is a burnable, solid organic type of waste. The waste can be classified either as hazardous or non-hazardous waste, depending on what kind of different substances the filter contains. Waste is considered hazardous if it among other things is a health threat, irritating to the airways, skin or mucous membranes, poisonous to breathe in or touch, if it can cause cancer, damage to foetus, be infectious or if it generates poisonous gases or leachate with one or several of the characteristics mentioned above. Waste is also considered to be hazardous if it is ecotoxic, that is if it can be harmful to the environment in the short or in the long run [14]. The Swedish law does not specify when a substance becomes hazardous. It is up to every operator to find out what different substances their waste contains and if, and in what quantity, they are a threat to health or to the environment [15]. Different regulations are applied for non-hazardous and hazardous waste. For an example special documentation and transportation is needed when handling hazardous waste [16].

According to the "waste management hierarchy" of the EU, production of waste should be avoided. If waste is produced it should be reused in the first place and be recycled in the second place. The energy in the material should be recycled, for example by incineration, if the material can not be reused or recycled. Putting waste in a landfill should be avoided. In Sweden, it is prohibited to send organic waste (containing $>5 \%$ total organic compound) to a landfill [17]. By reusing and recycling material and energy, natural resources are saved and less poisonous substances are dispersed in the environment [3]. 


\section{MATERIALS AND METHODS}

\subsection{Description of the filters}

The first filter (labeled A) was installed in a car wash in 2006 and the second filter (called B) was installed in a car wash in January 2008 [18].

\subsubsection{The filter construction}

The filter is placed on a flat surface on the ground near the car wash and consists of a tank placed on top of a polyethylene tarpaulin. The size of the tank is adapted to the quantity of treated wastewater. About $10 \mathrm{~m}^{3}$ of filter material is needed to treat the wastewater produced in a car wash where 5 000-6 000 cars are washed per year. For that size of a car wash, a tank that is 1.5 meters high with a diameter of 1.86 meters is needed. Figure 1 [19] shows a schematic picture of how a filter is constructed. In the figure a constructed wetland for sedimentation and aeration is included after the filter. The filters in this study lacked such constructed wetlands.

The filter is built to work in temperatures down to $-15^{\circ} \mathrm{C}$. The lower part of the inside of the tank is covered with $5 \mathrm{~cm}$ thick, isolating layers of styrofoam bricks and two protective polyethylene tarpaulins. A drain is situated in the middle of the tank through which treated, outgoing water leaves the tank. The drain is protected by a plastic pipe to prevent it from getting clogged by the filter material. The bottom of the tank is filled with baked clay pellets (leca) for drainage and the rest of the tank is filled with the filter material of peat and carboncontaining ash. Wastewater goes through the oil separator to the top of the filter where it is sprinkled out evenly through holes in a hose laying on top of the filter material. The hose and the filter material are covered by straw and a ventilated cover. The straw both isolates the filter material, constitutes a platform for bacteria to grow on (so does the peat) and provides nutrients for earth worms (Lumbricus terrestris) when such live in the peat. Earthworms aerate the filter material and contribute to the decomposition of organic substances in the filter [18].

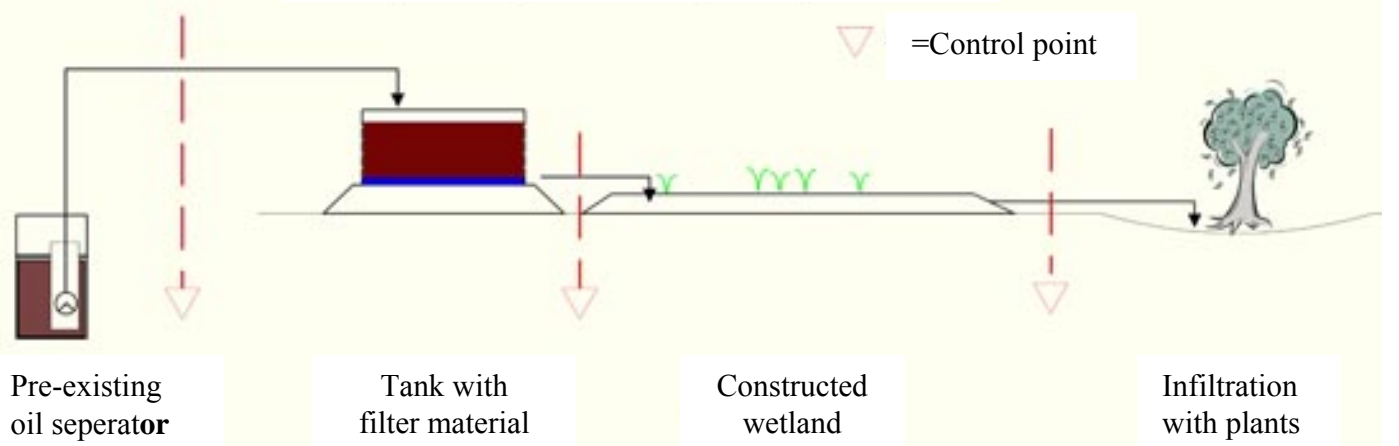

Figure 1. Schematic picture of how a filter can be constructed 
The filter needs supervision twice a year and to gain maximum treatment efficiency, it is recommended that the filter material be changed once every second year or after the maximum load of wastewater for two years is reached [19].

Information about the two filters investigated in this study is shown in Table 1 [18]. The peat in the filter material originated from the south of Sweden and was classified as H5 according to the von Post decomposition scale (raging from 1 to 10). The carbon-containing ash was a residual product from an incomplete combustion process at a pulp and paper industry in the south of Sweden [8]. Treated wastewater from both filters is directed to the central sewage treatment plant in the municipality of Kristianstad [20].

\subsection{Sampling from wastewater}

Samples of treated wastewater were taken at the control point shown in the middle of Figure 1. Four samples were taken from filter A. The first one was taken in January 2008 and the second one in March 2008. Metal and oil content was analysed and, as the results showed high oil content in both samples, new samples were taken in March 2008 and in May 2009. Only oil content was analyzed in those samples. In May a sample was also taken from wastewater going in the filter, at the control point to the left in Figure 1. Two samples were taken from filter B, one in January 2008 and the other one in March 2009. All samples were analyzed for metal and oil-index at a commercial laboratory (Eurofins Environment Sweden AB, Lidköping, Sweden).

To investigate if there was any risk of pollutants leaching from the filter material, a batch test according to Swedish standard 12357:4 was done with a following characterization of the leachate. Metal concentrations in the solid materials and in the eluates were determined at a reference laboratory (Section for Plant Ecology and Systematics, Lund University, Sweden). Analyses of the content of water and ash in the filter material and an effective heating value were determined at a commercial laboratory (Eurofins Environment Sweden AB, Lidköping, Sweden) to investigate if the energy content of the used material could be recovered at an incineration plant.

Table 1: Information about the two filters $A$ and B, received from Rosenqvist 2010.

\begin{tabular}{|c|c|c|c|}
\hline \multicolumn{2}{|l|}{ Car wash } & A & $\mathrm{B}$ \\
\hline \multicolumn{2}{|c|}{ Time in use (years): } & 4 & 2 \\
\hline \multicolumn{2}{|c|}{ Cars washed/year (200 I water/wash): } & $14000-15000$ & $7000-8000$ \\
\hline \multirow{3}{*}{$\begin{array}{l}\text { Treatment } \\
\text { capacity }\end{array}$} & \multirow{2}{*}{ per day: } & $8,0 \mathrm{~m}^{3}$ & $4,1 \mathrm{~m}^{3}$ \\
\hline & & 97 cars & 49 cars \\
\hline & per year $\left(\mathrm{m}^{3}\right)$ : & 2815 & 1435 \\
\hline \multicolumn{2}{|c|}{ Maximum load ( $\left.\mathrm{m}^{3} / \mathrm{day}\right)$} & 19.3 & 9.8 \\
\hline \multicolumn{2}{|c|}{ Included constructed wetland: } & No & No \\
\hline \multicolumn{2}{|c|}{ Contained Earth worms: } & No & Yes \\
\hline
\end{tabular}




\section{RESULTS AND DISCUSSION}

\subsection{Treated wastewater}

The analytical findings (mg/car) from the samples of wastewater from filter A and B [18] are shown in Table 2 together with the guiding values for wastewater used in car washes for passenger cars in the municipality of Kristianstad [6].

In the samples taken from filter A and B, only the content of oil compounds in the samples from A exceeded the guiding values at the time the samples were collected. Because of high content of oil compounds in the water, samples were retaken. The results from the new samples showed oil contents in the wastewater far below recommended guiding values. The high content of oil in the first samples were probably due to a problem with the oil separator. It is not investigated in this study if, and in that case how, a high content of oil in filtered wastewater has a negative effect on the peat and ash filter.

Samples are recommended to be gathered more frequently and controlled for content of oil in the wastewater entering the filter, due to the varying effect of the oil separator. Only one sample was taken from ingoing wastewater in this study. The result from that sample shows that when the content of oil in the wastewater is $500-700 \mathrm{mg}$ oil $/ \mathrm{car}$, the filter manages to treat the water down to $100 \mathrm{mg} / \mathrm{car}$. For a deeper analysis of the treatment effect of the filter samples should be taken from ingoing wastewater every time a sample is taken from the filter. Based on the results from the analyses, the conclusion in this study is that the filter of peat and carbon-containing ash works well to treat wastewater from passenger car washes, according to the municipality of Kristianstad's current guiding values. The guiding values could and should however be discussed. It is well known that products that are used in car

Table 2. Analytical findings concerning concentrations of metals and oil in treated wastewater (Out) from $A$ and $B$ and ingoing water (In) from A together with guiding values for wastewater produced per washed passenger car in Kristianstad municipality. All values given in $\mathrm{mg} / \mathrm{car}$.

\begin{tabular}{|c|c|c|c|c|c|c|c|c|}
\hline $\begin{array}{l}\text { Analyzed } \\
\text { substances }\end{array}$ & $\begin{array}{l}\text { Guiding } \\
\text { values } \\
\text { for } \\
\text { passenger } \\
\text { cars }\end{array}$ & $\begin{array}{c}\text { A } \\
\text { Out } \\
\text { Jan } \\
2008\end{array}$ & $\begin{array}{c}\text { Retake } \\
\text { A } \\
\text { Out } \\
\text { Mars } \\
2008\end{array}$ & $\begin{array}{c}\text { A } \\
\text { Out } \\
\text { Mars } \\
2009\end{array}$ & $\begin{array}{c}\text { Retake } \\
\text { A } \\
\text { In } \\
\text { May } \\
2009\end{array}$ & $\begin{array}{c}\text { Retake } \\
\text { A } \\
\text { Out } \\
\text { May } \\
2009\end{array}$ & $\begin{array}{c}\text { B } \\
\text { Out } \\
\text { Jan } \\
2008\end{array}$ & $\begin{array}{c}\text { B } \\
\text { Out } \\
\text { Mars } \\
2009\end{array}$ \\
\hline $\begin{array}{l}\mathrm{Pb}+\mathrm{Cr} \\
+\mathrm{Ni}\end{array}$ & 5,0 & 2,9 & - & 3,1 & - & - & 1,4 & 2,2 \\
\hline $\mathrm{Cd}$ & 0,10 & 0,020 & - & 0,020 & - & - & 0,03 & 0,02 \\
\hline $\mathrm{Zn}$ & 50 & 4,1 & - & 4,5 & - & - & 15 & 38 \\
\hline $\mathrm{Cu}$ & 75 & 4,9 & - & 3,2 & - & - & 0,4 & 3,4 \\
\hline $\begin{array}{l}\text { Oil } \\
\text { index* }\end{array}$ & 1500 & 3000 & 100 & 2800 & 500 & 100 & 70 & 1100 \\
\hline
\end{tabular}

- = missing value

* Oil index is a measurement for the total concentration of chains of hydrocarbon consisting of 10-40 carbon atoms. These are the most common lengths of hydrocarbons in oil from car washes. 
washes might contain substances harmful to the environment, for example surfactants and aromatic solvents [5]. The substances in the wastewater go down the drain, but it has not been investigated whether they are caught in the filter and are decom posed there or if they go straight through the filter. There are no guiding values at all for these types of substances in today's policy for wastewater from car washes in the municipality of Kristianstad. Hopefully this will change in the future. By using eco labelled products in the car wash and encouraging customers to do the same, operators can contribute to a reduced negative impact on the environment.

\subsection{Content of elements in used filter material}

Kängsepp et al. [8] analysed the content of chosen elements in unused filter material of peat and carbon-containing ash. Their analytical findings are shown in Table 3 together with the analytical findings for A and B and the mean values for the content of those elements in Swedish peat (background values) [10]. It is important to remember that the filter material is made of $75 \%$ peat and $25 \%$ ash from a paper and pulp industry when comparisons are made to the mean values for the natural, Swedish peat.

The analysed parameters in the used filter material were all similar to the background values for Swedish peat, except for $\mathrm{Cd}, \mathrm{Fe}$ and $\mathrm{Zn}$ in filter A. The higher content of those elements is probably due to the long period of use (four years) of that filter. By using the filters during two years as recommended, a less polluted waste product is gained.

Analytical findings ( $\mathrm{mg} / \mathrm{kg}$, dried weight) concerning chosen elements and dissolved organic carbon (DOC) in leachate from used filter material are shown in Table 4, together with limit values for leachate from non-hazardous waste allowed to be sent to a landfill [17].

The concentration of all analysed substances in leachate from the used filter material A and B were lower than or at the same level as the limit values for non-hazardous waste that is allowed to be put on a landfill. Only the content of dissolved organic carbon (DOC) in the leachate from filter A was slightly exceeding the limit value.

Table 3. Analytical findings concerning elements in used filter material from $A$ and $B$ together with the mean value of unused filter material and background values for an average in ashes from Swedish peat. The unit is in $\mathrm{mg} / \mathrm{kg}$ (dried weight).

\begin{tabular}{ccccc}
\hline $\begin{array}{c}\text { Analyzed } \\
\text { substances }\end{array}$ & $\begin{array}{c}\mathrm{A} \\
(\mathrm{mg} / \mathrm{kg} \mathrm{DW})\end{array}$ & $\begin{array}{c}\mathrm{B} \\
(\mathrm{mg} / \mathrm{kg} \mathrm{DW})\end{array}$ & $\begin{array}{c}\text { Unused } \\
\text { filter } \\
(\mathrm{n}=3) \\
(\mathrm{mg} / \mathrm{kg} \mathrm{DW})\end{array}$ & $\begin{array}{c}\text { Background values } \\
\text { (peat) } \\
(\mathrm{mg} / \mathrm{kg} \mathrm{DW})\end{array}$ \\
\hline $\mathrm{Cd}$ & 1,2 & 0,30 & 0,34 & 0,23 \\
\hline $\mathrm{Co}$ & 9,7 & 8,7 & 21 & 34 \\
\hline $\mathrm{Cr}$ & 32 & 24 & 46 & 120 \\
\hline $\mathrm{Cu}$ & 77 & 140 & 47 & 230 \\
\hline $\mathrm{Fe}$ & 7900 & 10000 & 14000 & 55 \\
\hline $\mathrm{Mo}$ & 4,2 & 3,1 & - & 100 \\
\hline $\mathrm{Ni}$ & 27 & 23 & 46 & 64 \\
\hline $\mathrm{Pb}$ & 21 & 22 & 29 & 230 \\
\hline $\mathrm{Zn}$ & 420 & 190 & 60 & \\
\hline
\end{tabular}


Table 4. Analytical findings ( $\mathrm{mg} / \mathrm{kg}$ dried weight) concerning leachate from $A$ and $B$ together with limit values for leachate from non-hazardous waste allowed to be sent to a landfill (at $\mathrm{L} / \mathrm{S} 10 \mathrm{l} / \mathrm{kg})$.

\begin{tabular}{cccc}
\hline $\begin{array}{c}\text { Analysed } \\
\text { substances } \\
(\mathrm{mg} / \mathrm{kg} \mathrm{DW})\end{array}$ & $\mathrm{A}$ & $\mathrm{B}$ & $\begin{array}{c}\text { Limit values } \\
\text { Non-hazardous waste }\end{array}$ \\
\hline $\mathrm{As}$ & 0,20 & 0,08 & 2,0 \\
\hline $\mathrm{Cd}$ & 0,003 & 0,002 & 1,0 \\
\hline $\mathrm{Cr}$ & 0,05 & 0,20 & 10 \\
\hline $\mathrm{Cu}$ & 0,46 & 0,44 & 0,20 \\
\hline $\mathrm{Hg}$ & 0,002 & 0,003 & 10 \\
\hline $\mathrm{Mo}$ & 0,52 & 0,19 & 10 \\
\hline $\mathrm{Ni}$ & 0,05 & 0,10 & 0,70 \\
\hline $\mathrm{Pb}$ & 0,01 & 0,05 & - \\
\hline $\mathrm{Sb}$ & 0,07 & 0,04 & 50 \\
\hline $\mathrm{Sn}$ & 0,004 & 0,02 & 800 \\
\hline $\mathrm{Zn}$ & 2,5 & 2,8 &
\end{tabular}

- = missing value

\subsection{Waste classification and handling}

Based on the results from the performed analyses, the waste material should be classified as non-hazardous waste. When classifying the filter material as waste it is important to consider the content of substances in the product used for washing and caring of the vehicles and the car wash. The products used can vary between car washes. It is up to every operator to have routines for gaining adequate knowledge about the products used and to ensure that the information and documentation about those products are updated [13]. Gathering information about what products have been used in the car washes where the filter material in this study comes from lies outside the boundaries of this study. Therefore it is not possible to classify the filter material as waste based solely on the results from the analyses done in this study. By only using eco labelled products in the car washes the possibility to classify the waste as nonhazardous increases.

\subsubsection{Effective heating value and content of water and ash in used filter material}

The effective heating value is the energy that theoretically can be extracted from a material when incinerated, minus the energy that is lost in the water vapor produced in the process. The more water a material holds and the more ash that is left after incineration, the lower is the effective heating value of the material [21]. A normal content of ash in peat is $2-6 \%, 8 \%$ is considered high. The normal content of water in peat used for incineration is $25-30 \%$ [22]. 
The mean water content in the two used filter materials was $70 \%$ and the mean content of ash was $29 \%$ (dried weight). The mean effective heating value of the used filter material was $17.5 \mathrm{MJ} / \mathrm{kg}$ (in dry weight). This is similar to values obtained for biological materials considered for incineration. Peat containing 50\% water and 2-6\% ash has an effective heating value of approx. $21,5 \mathrm{MJ} / \mathrm{kg}$ (dried weight) [21]. In delivered state the mean heating value was considerably lower, $3,6 \mathrm{MJ} / \mathrm{kg}$. If the material can be dried to about $25-50 \%$ of water content before use, it should work well for incineration. If incinerated, the energy in the material would be recovered. The ash produced could be used as ballast in road constructions or as cover on closed landfills, as long as hazardous leachate is not produced. The results from the leaching analysis showed that the leachate from used filter material contained only low concentrations of the elements analysed. In this study, it has not been investigated if the ashes produced if the filter material is incinerated give rise to hazardous leachate. An alternative use for the used filter material could be to mix it with contaminated soil. In that way the material should be totally reused and the biological, decomposing processes would be able to continue. This is fully in line with the second step in the waste management hierarchy of the EU.

\section{CONCLUSIONS}

A filter made of peat and carbon-containing ash works to treat wastewater from the studied car washes. The guiding values today in the municipality of Kristianstad can be questioned however. There are no guiding values concerning for example organic substances as surfactants and aromatic solvents, known to be harmful to organisms living in fresh water.

It is of high importance that the operator of a car wash has good knowledge of and control over which substances the products used in the facility are containing, to be able to classify the used filter material as waste. By using only eco labelled products the negative impact on the environment decreases, at the same time as the probability to classify the used filter material as non-hazardous waste increases.

The best way to handle used filter material after it has become waste is to reuse it in some way. As long as the knowledge about the content of non-analyzed substances is poor, incineration must be regarded as a good way to handle the waste from an environmental perspective, as both the energy in the material is recovered and the ash produced can be used as construction material.

\section{ACKNOWLEDGMENTS}

The authors acknowledge D. Rosenqvist, Laqua Treatment $\mathrm{AB}$, for help with sampling and for information about the filter construction.

\section{REFERENCES}

[1] SwedishEnvironmentalProtectionAgency. 2010. Sveriges miljömål - för ett hållbart samhälle. $\quad$ http://www.naturvardsverket.se/sv/Sveriges-miljomal--for-ett-hallbart-samhalle. [downloaded 2010-10-09]; (in Swedish)

[2] SwedishEnvironmentalProtectionAgency. 2009. Miljöpåverkan från avfall. http://www.naturvardsverket.se/sv/Produkter-och-avfall/Avfall/Mal-strategier-ochresultat/Miljopaverkan-fran-avfall. [downloaded 2010-10-09]; (in Swedish) 
[3] SwedishEnvironmentalProtectionAgency. 2009. Principer för hållbar avfallshantering. http://www.naturvardsverket.se/sv/Produkter-och-avfall/Avfall/Mal-strategier-ochresultat/Principer-for-avfallshantering. [downloaded 2010-10-09]; (in Swedish) [4] SwedishEnvironmentalProtectionAgency. 2005. Fordonstvättar.Utgåva 1. http://www.naturvardsverket.se/Documents/publikationer/620-8207-8.pdf. [downloaded 2010-10-09]; (in Swedish)

[5] HållSverigeRent. 2010. Miljöanpassad biltvätt. http://www.hsr.se/sa/node.asp?node=887. [downloaded 2010-10-10]; (in Swedish)

[6] KristianstadsKommun. 2005. Policy för krav på rening av avloppsvatten från fordonstvättar.

http://www.kristianstad.se/upload/Malgrupper/Foretag/dokument/lagar_vagledning/miljoskyd d/Policybiltvatt.pdf. [downloaded 2010-10-09]; (in Swedish)

[7] Kängsepp, P., 2008. Development and Evaluation of a Filter-Bed-Based System for Fullscale Treatment of Industrial Landfill Leachate. Doctoral dissertation, Department of Analytical Chemistry, Lund University, Sweden

[8] Kängsepp, P., et al., 2008. A batch-test-based approach towards an environmentally friendly adsorbent for leachate treatment of organic and inorganic pollutants. Unpublished manuscript

[9] Kängsepp, P., et al., 2008. Column studies aiming at identification of suitable filter materials for pollutant removal from landfill leachate. International Journal of Environment and Waste Management, 2(6): p. 506-525.

[10] SGU. 2010. Torv och torvmarker. http://www.sgu.se/sgu/sv/samhalle/energiklimat/torv/index.html. [downloaded 2010-10-10]; (in Swedish)

[11] Larsson, L., J. Rogbeck, and K. Håkansson, 2007, Passiva filterbarriärer - Vägledning. STATENS GEOTEKNISKA INSTITUT. (in Swedish)

[12] SFS 1998:808 Miljöbalk (1998:808) (in Swedish)

[13] SFS 1998:901 Förordning (1998:901) om verksamhetsutövares egenkontroll. (in Swedish)

[14] SFS 2001:1063 Avfallsförordning (2001:1063). (in Swedish)

[15] SwedishEnvironmentalProtectionAgency. 2010. Klassning av farligt avfall. http://www.naturvardsverket.se/sv/Produkter-och-avfall/Avfall/Lagar-och-regler-omavfall/Klassning-av-farligt-avfall. [downloaded 2010-10-09]; (in Swedish)

[16] LänstyrelsenVästraGötaland. 2010. Tillstånd - transporter av avfall. http://www.lansstyrelsen.se/vastragotaland/amnen/Miljoskydd/Avfall/transporteravfall_07031 9.htm. [downloaded 2010-10-09]; (in Swedish)

[17] NFS 2004:10 Naturvårdsverkets föreskrifter om deponering, kriterier och förfaranden för mottagning av avfall vid anläggningar för deponering av avfall. (in Swedish)

[18] Rosenqvist, D., 2010, Laqua Treatment AB, personal communication 2010-01-30

[19] LAQUA. 2010. Laqua Tvätt http://www.laqua.se/?m=washbuild\&p. [downloaded 2010-10-09]; (in Swedish)

[20] Åkesson, A.-K., 2010, Kristianstad kommun, Miljö- och hälsoskyddskontoret, personal communication 2010-02-17

[21] Bioenergiportalen. 2006. Exempel på bränsledata för olika bränslen. http://www.bioenergiportalen.se/?p=1590,. [downloaded 2008-06-19]; (in Swedish)

[22] Persson, J., 2010, Perstorp AB, personal communication 2010-03-12 